\title{
KARAKTERISTIK FISIKOKIMIA PETIS DARI AIR REBUSAN IKAN LAYANG (Decapterus sp.) DENGAN KOMBINASI BAHAN PENGISI
}

\section{Physicochemical Characteristics of Fish Paste from Shortfin Scad (Decapterus sp.) Boiled Fish Water with Filler Material Combinations}

\author{
Maulidya Julita Sari, Seftylia Diachanty, Irman Irawan, Bagus Fajar Pamungkas, \\ dan Ita Zuraida* \\ Universitas Mulawarman, Program Studi Teknologi Hasil Perikanan \\ Gn. Tabur, Kampus Gn. Kelua Samarinda, 75123, Indonesia \\ *Korespondensi penulis: itazuraida@gmail.com
}

Diterima: 25 Maret 2021; Direvisi: 11 Juni 2021; Disetujui: 23 Agustus 2021

\begin{abstract}
ABSTRAK
Petis dapat dibuat dari bahan-bahan dasar berupa kaldu hasil rebusan ikan pindang, kupang, atau udang dan bahan pengisi yaitu berbagai jenis tepung. Penggunaan bahan pengisi dimaksudkan untuk meningkatkan kualitas produk terkait karakteristik kimiawi dan kesukaan konsumen. Tujuan penelitian ini adalah untuk memahami karakteristik fisikokimia petis air rebusan ikan layang dengan kombinasi bahan pengisi. Bahan pengisi yang digunakan yaitu: (1) $20 \%$ tepung terigu, (2) $15 \%$ tepung terigu $+5 \%$ tepung tapioka, (3) $15 \%$ tepung terigu $+5 \%$ tepung beras, dan (4) $15 \%$ tepung terigu $+5 \%$ maizena. Parameter yang dianalisis terdiri atas proksimat, viskositas, warna, dan tingkat kesukaan (hedonik). Hasil penelitian menunjukkan bahwa kombinasi bahan pengisi berpengaruh nyata terhadap nilai proksimat petis (kadar abu, air, protein, lemak) dan sifat fisik (viskositas dan warna), namun tidak berpengaruh nyata terhadap nilai hedonik (warna, rasa, tekstur, aroma,dan kesukaan keseluruhan). Kadar air petis adalah $30-50 \%$ dengan protein $20-27 \%$ yang telah memenuhi standar SNI 1-2718-2013. Derajat putih petis $40,49-45,50 \%$ dengan viskositas 568,75-981,25 dPa's. Penambahan bahan pengisi tepung terigu dan tepung tapioka merupakan perlakuan terbaik yang menghasilkan petis dengan kadar air 32,89\%; abu $2,30 \%$; protein $24,05 \%$; lemak 3,63\%; karbohidrat $37,13 \%$; kecerahan (L) 50,93, (a*) 5,37, (b*) 23,10 , derajat putih $45,50 \%$, dan viskositas 981,25 dPa's. Berdasarkan parameter rasa $(6,55)$, tekstur $(6,35)$, aroma $(5,88)$, warna $(6,68)$ dan kesukaan keseluruhan $(7,03)$, data hasil analisis menunjukkan bahwa petis tersebut dapat diterima dengan baik oleh panelis.
\end{abstract}

KATA KUNCI : air rebusan ikan, petis, bahan pengisi, sifat fisikokimia

\begin{abstract}
Petis is made of broth from boiled fish, mussels, or shrimp as basic ingredients and filler materials of flour. The use of fillers is intended to improve product quality related to chemical characteristics and consumer preferences. This study aims to determine the physicochemical characteristics of petis with a combination of fillers. The fillers used are: (1) $20 \%$ wheat flour, (2) $15 \%$ wheat flour $+5 \%$ tapioca flour, (3) $15 \%$ wheat flour $+5 \%$ rice flour, and (4) $15 \%$ wheat flour + $5 \%$ cornstarch. Parameters analyzed include proximate, viscosity, color, and level of preference (hedonic). Data were analyzed using a completely randomized design with three replications, while the hedonic test results were analyzed using Kruskal-Wallis. The combination of fillers had a significant effect on proximate values (ash, moisture, protein, fat) and physical properties (viscosity and color), but had no significant effect on hedonic values (taste, color, odor, texture, and overall liking). The moisture content of petis was $30-50 \%$, with protein content $20-27 \%$, and has met the standard of SNI 1-2718-2013. The whiteness of the petis was 40.49-45.50\%, while the viscosity ranged from 568.75 to $981.25 \mathrm{dPa}$ 's. The addition of wheat flour and tapioca flour was the best treatment. This petis has a moisture content of $32.89 \% ; 2.30 \%$ ash; $24.05 \%$ protein; $3.63 \%$ fat; $37.13 \%$ carbohydrate; with brightness of $(L) 50.93$, $\left(a^{*}\right) 5.37,\left(b^{*}\right) 23.10$, whiteness of $45.50 \%$, and viscosity of 981.25 dPa's. The hedonic sensory test (scale 1-9) showed that this petis was well received by the panelists based on the parameters of taste (6.55), texture (6.35), aroma (5.88), color (6.68), and overall acceptance (7.03).
\end{abstract}

KEYWORDS: boiled fish liquid, fish paste, filler, physicochemical properties 


\section{PENDAHULUAN}

Ikan layang termasuk salah satu ikan pelagis kecil yang bernilai ekonomis tinggi dan termasuk dalam suku Carangidae. Ikan layang mengandung kadar air $76 \%$, protein $20,6 \%$, lemak $1,3 \%$, dan abu $1,4 \%$ (Nontji, 2002). Menurut data Kementerian Kelautan dan Perikanan (2019), total produksi ikan layang di Indonesia pada tahun 2018 sebesar 507.626,52 ton per tahun. Hal ini menunjukkan salah satu jenis ikan yang berpotensi untuk dapat dikembangkan menjadi produk olahan, antara lain melalui proses perebusan seperti ikan pindang adalah ikan layang. Perebusan akan menghasilkan banyak sisa cairan yang dikenal sebagai air rebusan. Hingga saat ini, air rebusan ikan belum dimanfaatkan secara optimal. Air rebusan ikan pindang masih mengandung komponen nutrisi seperti protein, lemak, vitamin, dan mineral (Oktavia, Mangunwijaya, Wibowo, Sunarti, \& Rahayuningsih, 2012). Air ini dapat dimanfaatkan untuk pengolahan lebih lanjut, salah satunya sebagai bahan baku petis ikan (Astawan, 2004). Saat ini, pemanfaatan limbah cairan rebusan pemindangan ikan baru sekitar $41 \%$ (Astuti, 2014).

Petis merupakan produk olahan hasil perikanan berbentuk pasta yang menyerupai bubur kental dengan aroma khas ikan atau udang, dan berwarna hitam atau cokelat tergantung pada bahan bakunya (Isnaeni, Swastawati, \& Rianingsih, 2014). Petis diolah dari air hasil proses penggaraman atau perebusan yang diuapkan kembali sehingga membentuk tekstur lebih padat menyerupai pasta (Astawan,2004). Secara keseluruhan, petis yang beredar di pasaran dapat dikelompokkan menjadi dua, yaitu petis dengan bahan baku sari udang dan petis dengan bahan baku sari ikan (Suprapti, 2001). Selain sari udang atau sari ikan, pembuatan petis juga menggunakan bahan pengisi. Penggunaan bahan pengisi bertujuan untuk memperbaiki tekstur, meningkatkan stabilitas, daya ikat air, aroma, dan karakteristik irisan produk (Sofyan, Ikrawan \& Yani, 2018). Penambahan bahan pengisi dapat meningkatkan kualitas dan kuantitas petis, penerimaan konsumen, serta nilai jualnya. Petis yang tidak menggunakan bahan pengisi cenderung memiliki tekstur yang encer dan memerlukan waktu pemasakan yang lama, yaitu sekitar 10 jam (Astawan, 2004). Umumnya, bahan pengisi yang digunakan pada pengolahan petis adalah tepung beras, terigu, tapioka, dan maizena. Penggunaan tepung ini terkait kemampuannya dalam membentuk adonan yang elastis dan tidak mudah hancur (Astawan, 2004; Fakhrudin, 2009; Singh, Singh, Kaur, Sodhi, \& Gill, 2003).

Beberapa penelitian pembuatan petis dari limbah hasil perikanan dengan penambahan bahan pengisi telah dilakukan. Isnaeni et al. (2014) melaporkan pembuatan petis dari cairan sisa pengukusan bandeng menggunakan tepung maizena, tepung tapioka, dan tepung terigu sebagai bahan pengisi. Sementara itu, Hernawati, Saokani, dan Heriansah (2017) melakukan pembuatan petis dari limbah padat ikan tongkol dengan bahan pengisi tepung terigu. Selanjutnya, Hidayati, Sumardianto, dan Romadhon (2016) membuat petis dari cairan sisa pemindangan ikan layang dengan penambahan bahan pengisi tepung terigu, sedangkan Sari dan Kusnadi (2015) melaporkan pembuatan petis dari kepala udang dengan penambahan tepung terigu, beras, dan tapioka sebagai bahan pengisi. Bahan pengisi umumnya digunakan pada produksi petis dengan tujuan memberikan nilai tambah, kuantitas, dan nilai jualnya. Namun di sisi lain, penambahan bahan pengisi dapat penurunan mutu dari petis tersebut. Tujuan dari penelitian ini untuk mengetahui karakteristik fisiko-kimia petis yang dihasilkan dari kombinasi bahan pengisi. Air rebusan ikan layang (Decapterus sp.) digunakan sebagai bahan dasar dengan menambahkan kombinasi bahan pengisi seperti tepung beras, tapioka, maizena, dan terigu.

\section{BAHAN DAN METODE}

\section{Bahan}

Penelitian ini menggunakan bahan baku utama ikan layang (Decapterus sp.) berukuran $15-20 \mathrm{~cm}$ yang diperoleh dari pasar tradisional di Samarinda. Ikan dibawa dengan cooler box ke laboratorium Teknologi Hasil Perikanan Universitas Mulawarman. Setelah itu dilakukan penyiangan, pencucian dan perebusan. Pembuatan petis dan variasi bahan pengisi dilakukan menggunakan bahan pendukung seperti tepung maizena, tapioka, beras, terigu, garam, gula merah, gula putih, bawang putih, lada, dan jeruk nipis. Adapun bahan untuk analisis meliputi iselenium, $\mathrm{H}_{2} \mathrm{SO}_{4}$ pekat, akuades, $\mathrm{NaOH} 40 \%, \mathrm{H}_{3} \mathrm{BO}_{3}$ indikator merah methyl, heksana, $\mathrm{HCl}$, dan bahan-bahan lain (analytical grade).

\section{Metode}

\section{Pembuatan bahan dasar petis ikan}

Bahan dasar pembuatan petis ini adalah air rebusan ikan layang. Proses perebusan ikan layang mengacu pada metode Sari dan Kusnadi (2015). Ikan layang berukuran panjang $\pm 20 \mathrm{~cm}$ dan lebar $\pm 5 \mathrm{~cm}$ yang telah melalui proses pencucian dan penyiangan ditimbang sebanyak $250 \mathrm{~g}$ (sekitar 12 ekor), kemudian diberi air perasan jeruk nipis sebanyak $5 \mathrm{~mL}$ untuk menghilangkan bau amis. Setelah itu, dilakukan penambahan air sebanyak $1000 \mathrm{~mL}$ dan direbus pada suhu $100^{\circ} \mathrm{C}$ selama \pm 20 menit. Air rebusan ikan disaring dengan saringan 100 mesh untuk kemudian digunakan sebagai bahan dasar pembuatan petis. 


\section{Pembuatan petis ikan}

Pembuatan petis mengacu pada prosedur yang digunakan oleh Sari dan Kusnadi (2015) dengan modifikasi. Tepung beras, maizena dan terigu merupakan bahan pengisi yang digunakan pada pembuatan petis. Air rebusan ikan disaring untuk menghilangkan sisa-sisa daging ikan. Air kemudian dipanaskan pada suhu $60^{\circ} \mathrm{C}$ selama 20 menit dan ditambahkan gula pasir ( $2 \%)$, gula merah ( $4 \%)$, garam $(1,5 \%)$, merica $(0,1 \%)$, serta bawang putih $(1 \%)$. Bahan pengisi yang digunakan adalah $\mathrm{PO}$ (tepung terigu sebagai kontrol 20\%), P1 (15\% tepung terigu $+5 \%$ tepung tapioka), P2 (15\% tepung terigu $+5 \%$ tepung beras), dan P3 (15\% tepung terigu $+5 \%$ tepung maizena). Pemanasan dilakukan selama sekitar 10 menit hingga adonan petis mengental. Masing-masing perlakuan dilakukan sebanyak tiga kali ulangan.

\section{Pengujian petis ikan}

Karakteristik fisikokimia petis dianalisis dengan parameter kadar abu, lemak, protein, air (BSN, 2006); kadar karbohidrat (AOAC, 2012); viskositas; warna, dan derajat putih (León, Mery, \& Pedreschi, 2005). Uji hedonik yang dilakukan adalah uji penilaian pada score sheet (skala 1-9) terhadap petis ikan dengan 40 orang panelis tidak terlatih menggunakan metode BSN (2015). Pengujian ini meliputi tekstur, aroma, warna, rasa, dan kesukaan keseluruhan.

\section{Analisis data}

Data yang diperoleh kemudian dianalisis menggunakan analisis sidik ragam (ANOVA), jika terdapat beda nyata antar perlakuan dilanjutkan dengan uji Tukey pada taraf kepercayaan 95\%. Parameter uji hedonik yang meliputi tekstur, aroma, warna, rasa, dan kesukaan keseluruhan dianalisis menggunakan Kruskal Wallis dan apabila terjadi pergeseran nilai $\alpha$ akan dianalisis kembali menggunakan uji Multiple Comparison. Keseluruhan data diolah menggunakan software Statistical Package For Social Science (SPSS) 24.

\section{HASIL DAN PEMBAHASAN}

\section{Kadar Air}

Tabel 1 menjelaskan nilai proksimat petis air rebusan ikan layang yang meliputi kadar abu, air, lemak, karbohidrat dan protein. Petis dari perlakuan penambahan bahan pengisi tepung terigu dan maizena (P3) memiliki nilai kadar air tertinggi $(37,56 \%)$ dan P0 (tepung terigu) dengan nilai kadar air terendah $(27,51 \%)$. Berdasarkan uji ANOVA kombinasi bahan pengisi memberikan pengaruh nyata $(p<0,05)$ terhadap kadar air petis dari air rebusan ikan layang. Penambahan tepung maizena (P3) menghasilkan petis dengan kadar air yang lebih tinggi. Hal ini dapat dikaitkan dengan pendapat Fakhrudin (2009) yang menyatakan bahwa dibandingkan tepung jenis lain, kemampuan mengikat air pada tepung maizena lebih baik. Kemampuan tepung maizena dalam mengikat air erat hubungannya dengan kandungan amilopektin yang dimilikinya yaitu sekitar 73\% (Daniyanti, 2005).

Adanya molekul amilopektin dengan rantai karbonnya yang bercabang pada tepung memungkinkan proses pengikatan molekul air (Apriliani, Haryati, \& Sudjatinah, 2019). Menurut

Tabel 1. Uji proksimat petis air rebusan ikan layang (Decapterus sp.) dalam berat basah Table 1. Proximate analysis of fish paste from shortfin scad (Decapterus sp.) boiled fish water in wet basis

\begin{tabular}{cccccc}
\hline $\begin{array}{c}\text { Perlakuan/ } \\
\text { Treatment }\end{array}$ & $\begin{array}{c}\text { Air/ } \\
\text { Moisture (\%) }\end{array}$ & $\begin{array}{c}\text { Abu/ } \\
\text { Ash (\%) }\end{array}$ & $\begin{array}{c}\text { Protein/ } \\
\text { Protein(\%) }\end{array}$ & $\begin{array}{c}\text { Lemak/ } \\
\text { Fat (\%) }\end{array}$ & $\begin{array}{c}\text { Karbohidrat/ } \\
\text { Carbohydrate (\%) }\end{array}$ \\
\hline P0 & $27.51 \pm 2.80^{\mathrm{a}}$ & $2.62 \pm 0.16^{\mathrm{b}}$ & $27.50 \pm 0.99^{\mathrm{c}}$ & $5.48 \pm 0.09^{\mathrm{c}}$ & $36.89 \pm 3.73^{\mathrm{ab}}$ \\
P1 & $32.89 \pm 0.48^{\mathrm{b}}$ & $2.30 \pm 0.14^{\mathrm{b}}$ & $24.05 \pm 0.38^{\mathrm{b}}$ & $3.63 \pm 0.28^{\mathrm{b}}$ & $37.13 \pm 0.24^{\mathrm{b}}$ \\
P2 & $31.76 \pm 1.54^{\mathrm{ab}}$ & $1.49 \pm 0.26^{\mathrm{a}}$ & $20.69 \pm 0.09^{\mathrm{a}}$ & $2.53 \pm 0.60^{\mathrm{ab}}$ & $43.53 \pm 0.60^{\mathrm{c}}$ \\
P3 & $37.56 \pm 1.73^{\mathrm{c}}$ & $2.57 \pm 0.13^{\mathrm{b}}$ & $22.59 \pm 0.21^{\mathrm{ab}}$ & $1.51 \pm 0.19^{\mathrm{a}}$ & $35.77 \pm 1.45^{\mathrm{a}}$ \\
\hline
\end{tabular}

Keterangan/Note:

Angka yang diikuti superskrip yang berbeda pada kolom yang sama menunjukkan berbeda nyata pada taraf kepercayaan $95 \%(p<0,05)$. (P0) tepung terigu, (P1) tepung terigu:tepung tapioka,(P2) tepung terigu:tepung beras, (P3) tepung terigu:tepung maizena/Values followed by different superscripts in the same column show a significant difference at the $95 \%$ confidence level $(p<0.05)$. (P0) wheat flour, $(P 1)$ wheat flour:tapioca flour, $(P 2)$ wheat flour:ice flour, $(P 3)$ wheat flour:cornstarch 
Fakhrudin (2009) terjadinya interaksi kimia antara tepung, protein dan air mengakibatkan peningkatan kadar air pada petis. Interaksi tersebut menyebabkan waktu pemasakan lebih lama dan air di dalam bahan tidak dapat lepas secara sempurna. Kadar air semua petis yang dihasilkan pada penelitian ini telah memenuhi persyaratan dalam SNI No. 1-2718-2013 yaitu $30-50 \%$ (BSN, 2013).

\section{Kadar Abu}

Berdasarkan Tabel 1 perlakuan bahan pengisi tepung terigu (P0) menghasilkan petis dengan kadar abu (berat basah) tertinggi $(2,62 \%)$ dan perlakuan bahan pengisi tepung terigu dan tepung beras(P2) menghasilkan petis dengan kadar abu terendah $(1,49 \%)$. Berdasarkan uji ANOVA kombinasi bahan pengisi memberikan pengaruh nyata $(p<0,05)$ terhadap kadar abu petis. Keempat jenis bahan pengisi mengandung kadar abu sekitar 2,24\%. Kadar abu tersebut berasal dari kandungan zat anorganik pada tepung. Fakhrudin (2009) menyatakan bahwa kadar abu petis dapat berasal dari penambahan tepung. Nilai kadar abu (berat basah) yang dihasilkan petis air rebusan ikan layang dalam penelitian ini sedikit lebih tinggi dari yang disyaratkan dalam SNI No 1-27182013, yaitu maksimal $1 \%$ (BSN, 2013). Hal ini diduga karena kombinasi bahan pengisi yang berbeda dapat meningkatkan kandungan zat anorganik pada petis, sehingga kadar abunya juga makin tinggi.

\section{Kadar Protein}

Tabel 1 memperlihatkan bahwa kadar protein (berat basah) tertinggi diperoleh dari perlakuan penambahan bahan pengisi tepung terigu (P0) sebesar $27,50 \%$ dan P2 (penambahan bahan pengisi tepung terigu dan tepung beras) dengan nilai terendah, yaitu $20,69 \%$. Berdasarkan uji ANOVA kombinasi bahan pengisi memberikan pengaruh nyata $(p<0,05)$ terhadap kadar protein petis. Penambahan bahan pengisi mempengaruhi kadar protein pada petis air rebusan ikan layang. Penggunaan bahan pengisi berupa tepung terigu menyebabkan kadar protein petis air rebusan ikan layang lebih tinggi dibandingkan bahan pengisi lainnya. Darmawan (2001) menyatakan bahwa penambahan tepung terigu dapat meningkatkan kadar protein produk dibandingkan dengan tepung maizena dan tepung tapioka. Hal ini dikarenakan kadar protein pada tepung terigu lebih tinggi dari tepung lainnya; kadar protein tepung terigu sebesar $11,80 \%$ (Kent, 1983), tapioka 1,1\% (Auliah, 2012), tepung beras dan maizena masing-masing 7,0\% dan 0,3\% (Departemen Kesehatan Republik Indonesia, 1980). Sementara itu, Setyowati (2002) mengatakan bahwa penambahan tepung maizena tidak mempengaruhi kadar protein produk karena rendahnya kandungan proteinnya. Nilai kadar protein (berat basah) petis air rebusan ikan layang memenuhi persyaratan dalam SNI No. 1-27182013, yaitu minimal 15\% (BSN, 2013).

\section{Kadar Lemak}

Tabel 1 menunjukkan, penambahan bahan pengisi tepung terigu $(\mathrm{PO})$ menghasilkan petis dengan kadar lemak (berat basah) tertinggi sebesar $5,48 \%$ dan P3 (penambahan bahan pengisi tepung terigu dan tepung maizena) dengan nilai terendah yaitu $1,51 \%$. Berdasarkan uji ANOVA kombinasi bahan pengisi memberikan pengaruh nyata $(p<0,05)$ terhadap kadar lemak petis dari air rebusan ikan layang. Perbedaan kadar lemak dari berbagai perlakuan dapat disebabkan kandungan lemak dari bahan pengisi. Kadar lemak tertinggi pada bahan pengisi dimiliki oleh tepung terigu, yaitu $1,20 \%$ (Kent, 1983), tepung tapioka 0,5\% (Auliah, 2012), tepung beras $0,3 \%$, dan tepung maizena tidak memiliki kandungan lemak (Departemen Kesehatan Republik Indonesia, 1980).

Lemak dapat berinteraksi dengan protein dari tepung, sehingga berperan penting dalam pembentukan adonan. Elliason (2006) melaporkan bahwa jaringan yang kuat dan elastis dari zat glutein juga berasal dari interaksinya dengan lemak. Penelitian sebelumnya menyebutkan bahwa perbedaan kadar lemak tersebut dapat mempengaruhi fisik dan cita rasa petis (Isnaeni et al., 2014). Namun demikian, kadar lemak pada petis memiliki pengaruh yang nyata, hal ini disebabkan adanya penambahan bahan pengisi yang berbeda, tetapi tidak berpengaruh terhadap penerimaan kualitas petis (BSN, 2013).

\section{Kadar Karbohidrat}

Tabel 1 menunjukkan P2 (tepung terigu dan tepung beras) menghasilkan kadar karbohidrat petis tertinggi sebesar $43,53 \%$ dan P3 ( tepung terigu dan tepung maizena) dengan nilai terendah yaitu $35,77 \%$. Hasil uji ANOVA menunjukkan bahwa kombinasi bahan pengisi memberikan pengaruh tidak nyata $(p>0,05)$ terhadap kadar karbohidrat. Tingginya kadar karbohidrat (berat basah) pada perlakuan penambahan tepung beras dapat dikaitkan dengan tingginya kadar karbohindrat pada tepung beras, yaitu sebesar $80 \%$ (Departemen Kesehatan Republik Indonesia, 1980). Terkait penambahan tepung, perlu dicermati adanya potensi efek kurang menguntungkan, yaitu penambahan yang terlalu banyak dapat mengakibatkan adonan menjadi terlalu keras dan tekstur menjadi padat (Fakhrudin, 2009). Dalam hal ini, pengaturan banyaknya air yang ditambahkan pada bahan yang berbahan dasar tepung merupakan solusinya karena air menentukan kepadatan adonan. 


\section{Viskositas}

Pengukuran viskositas memiliki prinsip mengukur ketahanan gesekan antara dua lampisan molekul yang berdekatan. Cairan yang mengalir disebabkan oleh adanya gesekan internal dari suatu material yang memiliki viskositas yang tinggi (Kurnianta, 2002). Nilai viskositas petis dari berbagai perlakuan bahan pengisi terdapat pada Tabel 2.

Tabel 2 memperlihatkan bahwa penambahan bahan pengisi tepung terigu dan tepung tapioka (P1) menghasilkan petis dengan viskositas tertinggi sebesar 981,25 dPa's dan P2 (bahan pengisi tepung terigu dan tepung beras) dengan viskositas terendah sebesar 568,75 dPa's. Berdasarkan uji ANOVA kombinasi bahan pengisi memiliki pengaruh yang nyata $(p<0,05)$ terhadap viskositas petis dari air rebusan ikan layang. Perbedaan ini dapat dikaitkan dengan penjelasan Sari (2011) yang menyatakan bahwa kandungan amilopektin yang tinggi pada tepung merupakan penentu viskositas. Dalam hal ini, amilopektin memberikan pengaruh yang lebih besar dalam pengentalan adonan dibandingkan amilosa (Fajar, Padaga, \& Susilo, 2016). Kandungan amilosa pada tepung terigu sebesar $28 \%$ dengan amilopektin $72 \%$ (Pradipta \& Widya, 2015). Kandungan amilosa $17 \%$ dan amilopektin $83 \%$ dimiliki oleh tepung tapioka (Utomo, Wahyuni, \& Wiyono, 2011). Kandungan amilosa pada tepung beras $22 \%$ dan amilopektinnya $78 \%$ (Wanita \& Wisnu, 2013). Kandungan amilosa $27 \%$ dan amilopektin $73 \%$ dimiliki oleh tepung maizena (Daniyanti, 2005). Utomo et al. (2011) menyatakan bahwa penambahan tepung tapioka memiliki kadar amilopektin tinggi dari tepung lainnya yaitu sebesar $83 \%$.

Menurut Imanningsih (2012) viskositas bahan pangan yang menggunakan maizena sebagai bahan pengisi akan menghasilkan tekstur yang lebih lembek dan lebih mengalir. Menurut Sumnu, Ndife, dan Bayindirli (1999) petis memiliki viskositas yang dipengaruhi oleh lama waktu pemasakan, jumlah bahan yang ditambahkan, dan proporsi bahan pengisi yang ditambahkan. Secara umum, faktor yang dapat mempengaruhi viskositas berupa gaya tarik antar molekul, ukuran molekul, temperatur dan jumlah molekul terlarut (Fitriyah, Susilo, \& Komar, 2013).

\section{Pengujian Warna}

Nilai lightness atau $\mathrm{L}$ pada pengujian warna menunjukkan tingkat kecerahan, redness atau nilai $a^{*}$ yang menggambarkan warna merah, dan yellowness atau $\mathrm{b}^{*}$ yang menandakan warna kuning. Semakin tinggi nilai L (Lightness) dapat diartikan petis semakin cerah, semakin tinggi nilai $a^{*}$ warna petis semakin merah, dan semakin tinggi nilai $b^{*}$ warna petis semakin kuning. Nilai uji warna petis terdapat pada Tabel 3.

Pengujian warna menunjukkan bahwa tingkat kecerahan $\left(L^{*}\right)$ petis berkisar antara 46,92-50,93. Petis dengan kombinasi bahan pengisi tepung terigu : tepung tapioka memiliki tingkat kecerahan tertinggi yaitu sebesar 50,93. Berdasarkan uji ANOVA kombinasi bahan pengisi memberikan pengaruh nyata $(p<0,05)$ terhadap warna $\left(L^{*}\right),\left(a^{*}\right),\left(b^{*}\right)$, dan derajat putih. Petis dengan kombinasi jenis bahan pengisi tepung tapioka (P1) memiliki nilai kecerahan lebih tinggi. Sari \& Kusnadi (2015) menyatakan jika kandungan protein suatu bahan baku lebih rendah maka produk yang dihasilkan akan lebih cerah. Fattah (1986) menambahkan warna cokelat yang muncul saat proses pemanasan atau pengeringan adalah akibat dari bereaksinya protein dalam bahan dengan gula pereduksi.

Tabel 2. Rerata viskositas petis air rebusan ikan layang (Decapterus sp.)

Table 2. Viscosity average of fish paste fromshortfin scad (Decapterus sp.) boiled fish water

\begin{tabular}{cc}
\hline Perlakuan/Treatment & Rerata Viskositas/Average of Viscosity (dPa's) \\
\hline P0 & $689.06 \pm 50.82^{\mathrm{ab}}$ \\
P1 & $981.25 \pm 79.54^{\mathrm{c}}$ \\
P2 & $568.75 \pm 0.00^{\mathrm{a}}$ \\
P3 & $815.75 \pm 146.01^{\mathrm{bc}}$ \\
\hline
\end{tabular}

Keterangan/Note :

Angka yang diikuti oleh superskrip yang berbeda pada kolom yang sama menunjukkan beda nyata pada taraf kepercayaan 95\% $(p<0,05)$. (P0) tepung terigu, (P1) tepung terigu: tepung tapioka, (P2) tepung terigu: tepung beras, (P3) tepung terigu: tepung maizena/Values followed by different superscripts in the same column show a significant difference at the $95 \%$ confidence level $(p<0.05)$. $(P 0)$ wheat flour, $(P 1)$ wheat flour:tapioca flour, (P2) wheat flour:rice flour, (P3) wheat flour:cornstarch 
Tabel 3. Rerata uji warna petis air rebusan ikan layang (Decapterus sp.)

Table 3. Color test of fish paste from shortfin scad (Decapterus sp.) boiled fish water

\begin{tabular}{ccccc}
\hline \multirow{2}{*}{$\begin{array}{c}\text { Perlakuan/ } \\
\text { Treatment }\end{array}$} & $\mathbf{L}^{*}$ & $\mathbf{a}^{*}$ & $\mathbf{b}^{*}$ & $\begin{array}{c}\text { Uji Warna/Color Test } \\
\text { White Degrees(\%) }\end{array}$ \\
\cline { 2 - 5 } & $47.96 \pm 1.30^{\mathrm{a}}$ & $6.59 \pm 0.05^{\mathrm{b}}$ & $24.56 \pm 0.55^{\mathrm{ab}}$ & $42.07 \pm 0.94^{\mathrm{ab}}$ \\
P0 & $50.93 \pm 0.08^{\mathrm{b}}$ & $5.37 \pm 0.07^{\mathrm{a}}$ & $23.10 \pm 0.12^{\mathrm{a}}$ & $45.50 \pm 0.13^{\mathrm{c}}$ \\
P1 & $46.92 \pm 0.25^{\mathrm{a}}$ & $7.42 \pm 0.07^{\mathrm{c}}$ & $25.86 \pm 0.51^{\mathrm{b}}$ & $40.49 \pm 0.01^{\mathrm{a}}$ \\
P2 & $49.57 \pm 0.04^{\mathrm{ab}}$ & $6.42 \pm 0.11^{\mathrm{b}}$ & $24.38 \pm 0.06^{\mathrm{ab}}$ & $43.63 \pm 0.08^{\mathrm{bc}}$ \\
\hline
\end{tabular}

Keterangan/Note :

Angka yang diikuti oleh superskrip yang berbeda pada kolom yang sama menunjukkan beda nyata pada taraf kepercayaan 95\% $(p<0,05)$. ( $\mathrm{P} 0)$ tepung terigu, ( $\mathrm{P} 1)$ tepung terigu: tepung tapioka, $(\mathrm{P} 2)$ tepung terigu: tepung beras, (P3) tepung terigu: tepung maizena/Values followed by different superscripts in the same column show a significant difference at the $95 \%$ confidence level $(p<0.05)$. (P0) wheat flour, $(P 1)$ wheat flour: tapioca flour, $(P 2)$ wheat flour: rice flour, $(P 3)$ wheat flour: cornstarch

Hasil analisa memperlihatkanbahwa tingkat kemerahan $\left(a^{*}\right)$ petis berkisar antara 5,37- 7,42. Petis dengan kombinasi bahan pengisi tepung terigu : tepung beras memiliki nilai tertinggi sebesar 7,42. Khalida (2006) menjelaskan bahwa warna merah pada petis disebabkan oleh tepung terigu yang memiliki warna lebih gelap dibanding tepung beras.

Tingkat kekuningan $\left(b^{*}\right)$ petis air rebusan ikan layang berkisar antara 23,10-25,86. Petis dengan kombinasi jenis bahan pengisi penambahan tepung beras (P2) memiliki tingkat kekuningan tertinggi sebesar 25,86 . Petis dengan kombinasi tepung terigu : tepung tapioka memiliki tingkat kekuningan terendah sebesar 23,10. Jika tingkat kekuningan semakin rendah, maka proprosi tepung tapioka semakin tinggi. Hal tersebut disebabkan tingkat kekuningan bahan pengisi semakin rendah sehingga proporsi penambahan yang semakin banyak serta derajat putih dari tepung tapioka yang cukup tinggi (Khalida, 2006)

Data hasil analisis tingkat derajat putih petis berkisar antara 40,49-45,50\%. Penurunan derajat putih petis diduga disebabkan karena adanya reaksi pencoklatan yang berlangsung selama proses pemasakan. Reaksi antara gugus amina bebas dan gula reduksi selama proses pemasakan petis dapat menyebabkan reaksi pencoklatan (reaksi maillard). Rasyid, Hartulistiyoso, \& Fardiaz, (2017) melaporkan bahwa adanya penyerapan energi selama pemasakan dapat menurunkan nilai derajat putih.

\section{Uji Hedonik}

Penambahan bahan pengisi tidak berpengaruh nyata $(p>0,05)$ pada kesukaan konsumen terhadap petis ikan layang. Nilai kesukaan terhadap tekstur, aroma, warna, rasa, dan kesukaan keseluruhan, dan nilai berkisar antara 5,88 sampai 7,03 (netral sampai suka). Hasil uji hedonik petis air rebusan ikan layang disajikan pada Tabel 4.

\section{Rasa}

Skor rasa petis berkisar antara 6,28-6,58 (agak suka). Menurut Fakhrudin (2009), penilaian mutu rasa oleh panelis dapat tidak berbeda nyata karena penambahan tepung,karena berbeda jenis akan menghasilkan rasa yang netral. Suatu bahan pangan yang membentuk rasa dari komponen penyusun, perlakuan dan atau pengolahan produk tersebut. Rasa suatu bahan pangan terbentuk dari komponen yang menyusun bahan tersebut, perlakuan dan atau pengolahan produk (Harjono, Zubaidah, \& Aryani, 2000). Hasil penelitian sebelumnya pada skor rasa petis limbah ikan bandeng (Chanos chanos Forsk) yang dilakukan oleh Isnaeni et al. (2014) menunjukkan nilai rata-rata mutu rasa yang tidak berbeda nyata dengan penambahan terigu, tapioka, dan maizena, yaitu masing-masing sebesar 7,60; 7,63; dan 6,93.

\section{Tekstur}

Tekstur petis dari air rebusan ikan layang dengan bahan pengisi tepung terigu dan tepung tapioka secara umum cukup kental, elastis dan lembut, sedangkan bahan pengisi tepung maizena menghasilkan tekstur petis yang sedikit lembut. Skor tekstur petis berkisar antara 6,30-6,43 (agak suka). Menurut Fakhrudin (2009), bahan pengisi yang digunakan pada penmbuatan petis akan mempengaruhi tekstur yang dihasilkan. Hasil penelitian sebelumnya pada petis limbah ikan bandeng (C. chanos Forsk) presto, nilai teksturnya berkisar $6,97-7,87$. Penambahan terigu menghasilkan nilai kesukaan terhadap tekstur tertinggi 
Tabel 4. Skor hedonik petis air rebusan ikan layang (Decapterus sp.) terhadap rasa, tekstur, aroma, warna, dan kesukaan keseluruhan

Table 4. Hedonic scores of fish paste from shortfin scad (Decapterus sp.) boiled fish water on taste, texture, odor, color, and overall acceptance

\begin{tabular}{cccccc}
\hline $\begin{array}{c}\text { Perlakuan/ } \\
\text { Treatment }\end{array}$ & $\begin{array}{c}\text { Rasa/ } \\
\text { Taste }\end{array}$ & $\begin{array}{c}\text { Tekstur/ } \\
\text { Texture }\end{array}$ & $\begin{array}{c}\text { Aroma/ } \\
\text { Odor }\end{array}$ & $\begin{array}{c}\text { Warna/ } \\
\text { Color }\end{array}$ & $\begin{array}{c}\text { Kesukaan Keseluruhan/ } \\
\text { Overall Acceptance }\end{array}$ \\
\hline P0 & $6.30 \pm 1.11^{\mathrm{a}}$ & $6.43 \pm 1.23^{\mathrm{a}}$ & $5.88 \pm 1.43^{\mathrm{a}}$ & $6.48 \pm 1.39^{\mathrm{a}}$ & $6.93 \pm 1.11^{\mathrm{a}}$ \\
P1 & $6.55 \pm 1.19^{\mathrm{a}}$ & $6.35 \pm 1.27^{\mathrm{a}}$ & $5.88 \pm 1.50^{\mathrm{a}}$ & $6.68 \pm 1.07^{\mathrm{a}}$ & $7.03 \pm 1.09^{\mathrm{a}}$ \\
P2 & $6.58 \pm 1.05^{\mathrm{a}}$ & $6.30 \pm 1.13^{\mathrm{a}}$ & $6.00 \pm 1.46^{\mathrm{a}}$ & $6.55 \pm 1.13^{\mathrm{a}}$ & $6.80 \pm 1.18^{\mathrm{a}}$ \\
P3 & $6.28 \pm 1.15^{\mathrm{a}}$ & $6.38 \pm 1.27^{\mathrm{a}}$ & $5.98 \pm 1.45^{\mathrm{a}}$ & $6.48 \pm 1.13^{\mathrm{a}}$ & $6.80 \pm 1.09^{\mathrm{a}}$ \\
\hline
\end{tabular}

Keterangan/Note:

Angka yang diikuti huruf yang sama menunjukkan tidak ada beda berdasarkan analisis ANOVA. (P0) tepung terigu, $(\mathrm{P} 1)$ tepung terigu:tepung tapioka, $(\mathrm{P} 2)$ tepung terigu:tepung beras, $(\mathrm{P} 3)$ tepung terigu:tepung maizena. Keterangan Skor: 1 = amat sangat tidak suka, 2 = sangat tidak suka, $3=$ tidak suka, $4=$ agak tidak suka, $5=$ netral, $6=$ agak suka, 7 = suka, 8 = sangat suka, 9 = amat sangat suka/Values followed by the same letter show no difference based on ANOVA analysis. (P0) wheat flour, (P1) wheat flour: tapioca flour, $(P 2)$ wheat flour: rice flour, $(P 3)$ wheat flour: cornstarch Score Description: 1 = extremely dislike, 2 = very dislike, $3=$ dislike, $4=$ slightly dislike, $5=$ neutral, $6=$ slightly like, 7 = like, 8 = very like, 9 = extremely like

$(7,87)$, penambahan tapioka menghasilkan nilai kesukaan 7,10, dan penambahan maizena menghasilkan nilai kesukaan tekstur terendah yaitu 6,97 (Isnaeni et al., 2014).

Tekstur lembut dan kental pada petis dapat dipengaruhi oleh kandungan amilopektin yang tinggi pada tepung. Sementara itu, kandungan gluten pada tepung tapioka, maizena dan beras lebih rendah dibandingkan tepung terigu sehingga dapat menghasilkan tekstur petis yang lebih lembut (Fakhrudin, 2009). Gluten pada tepung terigu merupakan protein utama yang tersusun dari gliadin sebesar $20-25 \%$ dan glutein sebesar $35-40 \%$ (Fennema, 1996). Ariswati, Windi, dan Dimas (2013) menyatakan bahwa tekstur petis dapat dipengaruhi oleh adanya gluten. Kandungan gluten yang terdapat pada tepung terigu memiliki karakteristik tekstur yang kenyal dan elastis, hal tersebut sesuai dengan kriteria yang diharapkan ada pada petis.

\section{Aroma}

Skor aroma petis berkisar 5,88-6,00 (netral dan agak suka). Aroma ikan pada petis yang dihasilkan secara umum tidak terlalu tajam. Menurut DeMan (1997), proses perebusan dapat menguapkan sebagian senyawa-senyawa yang bersifat volatil. Hal inilah yang kemungkinan menyebabkan aroma ikan pada petis tidak terlalu kuat. Penambahan tepung yang cenderung netral juga mengurangi aroma ikan pada petis. Zahrotin (2013) menyatakan bahwa bau amis yang dihasilkan oleh produk olahan ikan dapat dikurangi dengan penambahan tepung, karena tepung mempunyai aroma netral. Selain itu, aroma sedap pada produk dapat ditingkatkan dengan penambahan bumbu-bumbu yang tepat. Hasil penelitian sebelumnya pada petis limbah ikan bandeng ( $C$. chanos Forsk) presto menunjukkan nilai aroma berkisar 7,50-7,63. Penambahan tepung tapioka menghasilkan nilai kesukaan terendah terhadap aroma petis $(7,50)$, sedangkan tepung maizena dan tepung terigu memiliki nilai kesukaan yang tidak berbeda nyata, yaitu 7,63 dan 7,60 (Isnaeni et al., 2014).

\section{Warna}

Skor warna petis berkisar 6,48-6,68 (agak suka). Penggunaan tepung tapioka menghasilkan penilaian yang tinggi pada panelis terhadap warna petis. Substitusi tepung tapioka dapat menghasilkan produk petis yang lebih cerah (Sari \& Kusnadi, 2015). Menurut Winarno (2008) tepung tapioka yang tergelatinisasi akan menghasilkan gel yang berwarna putih agak bening. Pada penelitian sebelumnya, nilai kesukaan panelis terhadap warna petis instan berkisar 5,056,00 (Sari \& Kusnadi, 2015).

\section{Kesukaan Keseluruhan}

Skor kesukaan keseluruhan petis air rebusan ikan layang berkisar 6,80-7,03 (agak suka dan suka). Kesukaan keseluruhan meliputi rasa, tekstur, aroma dan warna petis. Perlakuan dengan penambahan bahan pengisi tepung terigu dan tepung tapioka (P1) memiliki nilai tertinggi yaitu 7,03 (suka). Pada penelitian Isnaeni et al. (2014) penambahan terigu 
tapioka merupakan perlakuan yang paling disukai dengan nilai 7,63. Irmawati, Ishartani, dan Affandi (2014) menjelaskan bahwa aspek warna, rasa, tekstur dan aroma pada makanan dapat diukur dari daya terima keseluruhan. Pada penelitian sebelumnya, rerata nilai kesukaan keseluruhan panelis pada petis instan berkisar 4,10-5,45 (Sari \& Kusnadi, 2015).

\section{KESIMPULAN}

Hasil penelitian menunjukkan bahwa petis dengan kombinasi bahan pengisi tepung terigu 15\%: tepung tapioka 5\% (P1) memiliki karakteristik fisikokimia yang terbaik. Petis ini memiliki kadar air 32,89\%; abu $2,30 \%$; protein $24,05 \%$; lemak $3,63 \%$; karbohidrat $37,13 \%$; warna $\left(L^{*}\right) 50,93\left(a^{*}\right) 5,37\left(b^{*}\right) 23,10$ derajat putih $45,50 \%$ dan viskositas 981,25 dPa's. Petis dari air rebusan ikan layang tersebut secara hedonik (skala 1-9) dapat diterima oleh panelis berdasarkan parameter rasa $(6,55)$, tekstur $(6,35)$, aroma $(5,88)$, warna $(6,68)$, dan kesukaan keseluruhan $(7,03)$. Dengan kadar air $30-50 \%$ dan protein $20-27 \%$ petis air rebusan ikan layang ini telah memenuhi standar SNI 1-27182013. Penambahan bahan pengisi tidak mempengaruhi kesukaan konsumen terhadap petis ikan dengan ratarata nilai kesukaan terhadap tekstur, aroma, warna, rasa, dan kesukaan keseluruhan berkisar antara 5,88 hingga 7,03 (netral sampai suka). Perlakuan penambahan bahan pengisi dengan komposisi hasil penelitian ini dapat meningkatkan kualitas petis yang ada di pasaran terutama dalam hal karekteristik fisikokimianya. Kandungan gizi yang terdapat pada bahan pengisi dapat meningkatkan kandungan gizi dan nilai tambah dari petis ikan serta dapat memperbaiki tekstur dan daya ikat air petis ikan.

\section{UCAPAN TERIMA KASIH}

Terima kasih diucapkan kepada Fakultas Perikanan dan IImu Kelautan, Laboratorium Teknologi Hasil Perikanan, Laboratorium Biokimia Fakultas Matematika dan IImu Pengetahuan Alam, dan Laboratorium Produksi dan Teknologi Peternakan Universitas Mulawarman yang telah membantu menyediakan fasilitas sehingga penelitian ini dapat terlaksana.

\section{DAFTAR PUSTAKA}

Apriliani, P., Haryati, S., \& Sudjatinah. (2019). Berbagai konsentrasi tepung maizena terhadap sifat fisikokimia dan organoleptik petis udang. Jurnal Teknologi Pertanian, 1-9.

Ariswati, R., Windi, A., \& Dimas, R. A. M. (2013). Substitusi tepung tapioka dalam pembuatan takoyaki. Jurnal Teknosains Pangan, 2 (1), 1-10.
Association of Official Analytical Chemist (AOAC). (2012). Official Method of analysis of official analytical ofchemist. The Association of Official AnalyticalChemist, Inc. Arlington: Virginia.

Astawan. (2004). Petis si hitam lezat bergizi.Retrieved from http://cybertravel.cbn.net.id/cbprtl/cybertravel/ main.aspx on 10 February 2020.

Astuti, A. D. (2014). Pemanfaatan limbah cair pemindangan ikan. Jurnal Litbang, X(2), 114-122. doi: 10.33658/jl.v10i2.83

Auliah, A. (2012). Formulasi kombinasi tepung sagu dan jagung pada pembuatan mie. Jurnal Chemica, 13(2), 33 -38. doi: 10.35580/chemica.v13i2.624

Badan Standardisasi Nasional (BSN). (2006). Cara uji kimia-bagian 1:penentuan kadar abu, kadar air, kadar lemak, dan kadar protein pada produk perikanan SNI 01-2354.2006. Jakarta: Badan Standardisasi Nasional.

Badan Standardisasi Nasional (BSN). (2013).Produk petis udang SNI-1-2718-2013.Jakarta: Badan Standardisasi Nasional.

Badan Standardisasi Nasional (BSN). (2015).Pedoman pengujian sensori pada produk perikananSNI 2346:2015. Jakarta: Badan Standardisasi Nasional.

Daniyanti, D. (2005). Pengaruh perbedaan proporsi filler tepung maizena terhadap komposisi kimia, kualitas fisik dan organoleptik beef nuggets. Skripsi. Fakultas Peternakan. Universitas Gadjah Mada. Yogyakarta.

Darmawan, M. (2001). Pembuatan frankfurter ikan patin dengan berbagai jenis bahan pengisi. Skripsi. Institut Pertanian Bogor. Bogor.

DeMan, J. M. (1997). Kimia makanan. Institut Teknologi Bandung. Bandung.

Departemen Kesehatan Republik Indonesia. (1980). Materia medika Indonesia Jilid IV. Jakarta: Direktorat Pengawasan Obat dan Makanan. p.77, 185.

Elliason. (2006). Starch in food, structure, functions and applications. Woodhead Publishing Limited and CRC Press LLC : USA.

Fajar, F., Padaga, M. Ch., \& Susilo, A. (2016). Kualitas petis daging dengan sumber pati berbeda. Jurnal IImu dan Teknologi Hasil Ternak, 11(1), 8-21.doi: 10.21776/ub.jitek.2016.011.01.2.

Fakhrudin, A. (2009). Pemanfaatan air rebusan kupang putih (Curbula faba Hinds) untuk pengolahan petis dengan penambahan berbagai pati-patian. Skripsi. Fakultas Perikanan dan IImu Kelautan, Institut Pertanian Bogor. Bogor.

Fattah, M. A. (1986). Pengaruh proses dan bahan yang digunakan terhadap mutu petis udang jawa timur berdasarkan nilai gizi yang dikandungnya. Pusbinlat Industri: Bogor.

Fennema, O. R. (1996). Food chemistry third edition. Marcel Dekker Inc : New York.

Fitriyah, R. H., Susilo, B., \& Komar, N. (2013). Studi pengaruh penambahan air dan suhu pemanasan terhadap viskositas petis ikan. Jurnal Keteknikan Pertanian Tropis dan Biosistem. 1(2), 29-34.

Harjono, Zubaidah, E., \& Aryani, F. N. (2000). Pengaruh proporsi tepung beras ketan dengan tepung tapioka 
dan penambahan telur terhadap sifat fisik dan organoleptik kue semprong. Jurnal Makanan Tradisional Indonesia.

Hernawati, J., Saokani, \& Heriansah. (2017). Pengaruh penambahan garam terhadap karakteristik petis berbahan limbah padat ikan tongkol (Euthynnus affinis). Jurnal Balik Diwa, 8(1), 8-12.

Hidayati, A. A., Sumardianto, \& Romadhon. (2016). Pengaruh penambahan tinta cumi-cumi (Loligo sp.) dengan konsentrasi yang berbeda terhadap kualitas petis limbah ikan pindang. Jurnal Pengolahan dan BioteknologiHasil Perikanan. 5(1), 2442-4145.

Imanningsih, N. (2012). Profil gelatinisasi beberapa formulasi tepung-tepungan untuk pendugaan sifat pemasakan. Panel Gizi Makan, 35(1),13-22.

Irmawati, F. M. D., Ishartani, \& Affandi, D. R. (2014). Pemanfaatan tepung umbi garut (Maranta arundinacea L.) sebagai pengganti terigu dalam pembuatan biskuit tinggi energi protein dengan penambahan tepung kacang merah (Phaseolus vulgaris L.). Jurnal Teknosains Pangan, 3(1),3-14.

Isnaeni, A. N., Swastawati, F., \& Rianingsih, L. (2014). Pengaruh penambahan tepung yang berbeda terhadap kualitas produk petis dari cairan sisa pengukusan bandeng (Chanos Chanos Forsk) Presto. Jurnal Pengolahan dan Bioteknologi Hasil Perikanan, 3(3), 40-46.

Kementerian Kelautan dan Perikanan (KKP). (2019). Statistik perikanan tangkap laut produksi Tahun 2018. Indonesia. https://kkp.go.id/setjen/satudata/ artikel/9669-kelautan-dan-perikanan-dalam-angka2019-telah-terbit.

Kent, N. L. (1983). Technology of cereal (3rd ed). Pergamon Press:Sydney.

Khalida, R. N. (2006). Pengaruh jenis dan konsentrasi bahan pengisi terhadap sifat fisik, kimia dan organoleptik petis instan. Skripsi. Fakultas Teknologi Pertanian. Universitas Brawijaya. Malang.

Kurnianta, M. J. (2002). Profil kandungan logam berat cadmium (Cd) dan krom ( $\mathrm{Cr}$ ) dalam daging kupang beras (Tellina versicolo). Skripsi. Fakultas Matematika dan IImu Pengetahuan Alam. Universitas Jember. Jember.

León, K., Mery, D., \& Pedreschi, F. (2005). Color measurements in $L^{*} a^{*} b^{*}$ unit from RGB digital unit.Universidad de Santiago de Chile (USACH), Santiago.

Nontji, A. (2002). Laut nusantara. Jakarta: PT. Djambatan,

Oktavia, D. A., Mangunwijaya, D., Wibowo, S., Sunarti, T. C., \& Rahayuningsih, M. (2012). Pengolahan limbah cair perikanan menggunakan konsorsium mikroba indigenous proteolitik dan lipolitik. Agrointek, 6(2), 65-71.

Pradipta, I. B. Y. V., \& Widya D. W. P. (2015). Pengaruh proporsi tepung terigu dan tepung kacang hijau serta subtitusi dengan tepung bekatul dalam biskuit. Jurnal Pangan dan Agroindustri. 3(3),793-802.

Rasyid, N. P., Hartulistiyoso, E., \& Fardiaz, D. (2017). Aplikasi microwave untuk disinfestasi Tribolium castaneum (Herbst.) serta pengaruhnya terhadap warna dan karakteristik amilografi terigu. Jurnal Agritech, 37(2), 183-191. doi: 10.22146/ agritech. 11255 .

Sari, V. R., \& Kusnadi, J. (2015). Pembuatan petis instan (kajian jenis dan proporsi bahan pengisi. Jurnal Pangan dan Agroindustri. 3(2), 381-389.

Sari, M. (2011). Maizena sebagai alternatif pengganti pektin dalam pembuatan selai belimbing (Averrhoa carambola L.). Jurnal Sains Teknologi, 3(1), 44-51. doi: 10.31958/js.v3i1.32.

Setyowati, M. T. (2002). Sifat fisik, kimia dan palatabilitas nugget kelinci, sapi dan ayam yang menggunakan berbagai tingkat konsentrasi tepung maizena. Skripsi. Fakultas Peternakan, Institut Pertanian Bogor:Bogor.

Singh, N., Singh, J., Kaur, L., Sodhi, N. S., \& Gill, B. S. (2003). morphological, thermal and rheological of starches from different botanical sources. Food Chemistry, 81, 219-231. doi: 10.1016/S03088146(02)00416-8.

Sofyan, I., Ikrawan, Y., \& Yani, L. (2018). Pengaruh konsentrasi bahan pengisi dan sodium tripolyphosphate (Na5P3O10) terhadap karakteristik sosis jamur tiram putih (Pleurotus ostreatus). Pasundan Food Technology Journal, 5(1), 25-36.

Sumnu, G., Ndife, M. K., \& Bayindirli, L. (1999). Effects of sugar, protein and water content on wheat starch gelatinization due to microwave heating. European Food Research and Technology, 209(1), 68-71.

Suprapti, L. (2001). Membuat Petis Teknologi Tepat Guna. Yogyakarta: Kanisius.

Utomo, D., Wahyuni, R., \& Wiyono, R. (2011). Pemanfaatan ikan gabus (Ophiocephalus striatus) menjadi bakso dalam rangka perbaikan gizi masyarakat dan upaya meningkatkan nilai ekonomisnya. Teknologi Pangan : Media Informasi dan Komunikasi Ilmiah Teknologi Pertanian, 1(1). doi: 10.35891/tp.v1i1.476

Wanita, Y. P., \& Wisnu, E. (2013). Pengaruh cara pembuatan mocaf terhadap kandungan amilosa dan derajat putih tepung. Prosiding Seminar Hasil Penelitian Tanaman Aneka Kacang dan Umbi.

Winarno. (2008). Kimia pangan dan gizi. Jakarta: Gramedia.

Zahrotin, R. (2013). Penambahan tepung ganyong terhadap organoleptik, kandungan kalsium dan kalori pada bakso belut. Artikel Karya IImiah. IKIP PGRI Semarang. 